Bangladesh J. Bot. 50(3): 819-829, 2021 (September) SpecialＤOI: https://doi.org/10.3329/bjb.v50i5.56433

\title{
EFFECTS OF TILLAGE METHODS ON SOIL PHYSICAL PROPERTIES AND CROP YIELD IN ARID AREA OF NORTHWEST CHINA
}

\author{
JUAN LI ${ }^{* 1,2,3,4}$, ZHEN GUO ${ }^{1,3,4}$ AND JIAWEI WANG ${ }^{1,3,4}$ \\ Institute of Land Engineering and Technology, Shaanxi Provincial Land Engineering \\ Construction Group Co. Ltd., Xi'an, Shaanxi 710075, China
}

Keywords: Weibei highland, Tillage method, Soil bulk density, Spring maize, Yield, Water use efficiency

\begin{abstract}
Effects of no-tillage, deep tillage and tillage on soil physical properties and maize yield in Weibei dryland were studied through field experiments from 2008 to 2010. The results showed that the soil bulk density was the highest under no-tillage treatment. The maximum field water holding capacity and saturated water content were both the highest under deep-plowing treatment, which were 29.66 and $31.31 \%$, respectively. Under the condition of balanced fertilization, during the growth period of maize, the average soil water storage of no-tillage and deep-plowing treatment was 44.2 and $34.6 \mathrm{~mm}$ higher than that of ploughing treatment. The yield, water use efficiency and net income of deep-plowing treatment with balanced fertilization were the highest among three combinations of tillage. It can be seen that the treatment of deep loosening with balanced fertilization is the best combination of tillage and fertilization in continuous cropping corn field in Weibei Arid Plateau.
\end{abstract}

\section{Introduction}

The Weibei Arid Plateau in Shaanxi Province is located in the gully region of the southern tableland and residual plateau of the Loess Plateau. The annual precipitation is $420-700 \mathrm{~mm}$, belonging to the semi-humid and arid region of the warm temperate zone. The total amount of precipitation is limited with the scarce surface water resources, the annual variability and seasonal variability are large which indicates that it is a typical dry farming area (Song et al. 2004, Zhou et al. 2007). Drought stress and barren soil are the main limiting factors of crop production in the Loess Plateau (Huang et al. 2006). Therefore, it has become the focus of dry farming research to take appropriate agricultural technical measures to reduce non-productive water consumption, increase water production efficiency, improve ecological environment and increase crop yield (Ji et al. 1998, Wang et al. 2004, Shi et al. 2006). Some studies have shown that conservation tillage can increase soil water content, store water and preserve soil moisture, improve soil texture and increase yield (Zhang et al. 2005, Li et al. 2006). Some scientists had shown that conservation tillage can not only increase surface soil moisture and promote crop growth and development, but also realize the use of autumn rain in spring, increase yield and increase income (Hatfield et al. 2001, Fang et al. 2003, Liu et al. 2004, Zheng 2004, Li et al. 2006,). However, researches on the combination of soil fertility fertilization and conservation tillage measures are limited. For the study of dry land, it is expected to strengthen the agricultural scientific farming and cultivation system in arid areas, and how to make efficient use of water resources is also the focus of the following research. Studying the agricultural characteristics in early dry areas can better serve the

*Author for correspondence: <lijuan8136@163.com>. ${ }^{1}$ Shaanxi Provincial Land Engineering Construction Group Co., Ltd., Xi' an 710075, China. ${ }^{2}$ College of Forestry, Northwest A\&F University, Yangling 712100, China. ${ }^{3}$ Institute of Land Engineering and Technology, Shaanxi Provincial Land Engineering Construction Group Co. Ltd., Xi'an 710021, China. ${ }^{4}$ Key Laboratory of Degraded and Unused Land Consolidation Engineering, the ministry of Natural and Resources, Xi'an 710021, China. 
development of modern agriculture. Cultivation measures can improve soil properties and increase productivity, so it is of great significance to explore the practical farming methods in agricultural production in arid areas for promoting the sustainable development of agriculture in this region.

This study combined "regulating water by fertilizer" effect of fertilization measures with "storing water and preserving soil moisture" effect of conservation tillage effect, and explored the dynamic changes of soil moisture and yield effect in continuous cropping corn field under the combination of the two measures. Thus effects of water storage and soil moisture conservation, increase of yield and income under different tillage treatments were analyzed. The conservation tillage models adapted to the local precipitation resources and maize planting system were evaluated and selected in order to provide a scientific basis for sustainable water use and growth of yield and income in continuous cropping maize fields in Weibei Arid Plateau.

\section{Materials and Methods}

The experiment was set in Ganjing Town, Heyang County, Shaanxi Province (Northern latitude: $34^{\circ} 10^{\prime}-36^{\circ} 20^{\prime}$, east longitude: $106^{\circ} 20^{\prime}-110^{\circ} 40^{\prime}, 910 \mathrm{~m}$ in elevation), which is a typical semi-humid and drought-prone area in the eastern gully region of Weibei Arid Plateau. The average annual precipitation of $420-700 \mathrm{~mm}$, is mainly concentrated in July, August and September, the interannual precipitation distribution is uneven (Table 1). The annual evaporation is $1832.8 \mathrm{~mm}$, and the dryness is 1.5 . The experimental soil is black loam, which belongs to middle loam, with thick soil layer and strong ability of water storage and fertilizer conservation.

Table 1. Monthly precipitation of Heyang Station from 2008 to 2010 (mm).

\begin{tabular}{lllllllllllllllll}
\hline Year & Jan. & Feb. & Mar. & Apr. & May & Jun. Jul. & Aug. & Sep. & Oct. Nov. Dec. Annual & $\begin{array}{l}\text { Precipitation } \\
\text { precipi- } \\
\text { during growth } \\
\text { period }\end{array}$ \\
\hline 2008 & 29.1 & 8.3 & 13.0 & 31.7 & 23.5 & 95.7 & 54.4 & 123.5 & 65.2 & 15.0 & 0.0 & 0.0 & 459.4 & 315.0 \\
2009 & 1.2 & 23.5 & 19.8 & 12.8 & 133.5 & 46.8 & 46.6 & 96.8 & 52.4 & 24.8 & 37.4 & 2.3 & 501.0 & 386.0 \\
2010 & 0.0 & 0.0 & 16.8 & $14.9-$ & 40.3 & 44.3 & 56.7 & 127.5 & 123.4 & 39.1 & 0.0 & 0.0 & 451.8 & 390.7 \\
$1976-$ & 5.6 & 9.3 & 19.6 & 31.2 & 44.1 & 57.4 & 111.9 & 114.7 & 77.3 & 46.7 & 15.3 & 5.2 & 538.2 & 380.0 \\
2006 & & & & & & & & & & & & & & & \\
Av. & 9.0 & 10.3 & 18.3 & 25.2 & 61.1 & 61.1 & 67.4 & 115.6 & 79.6 & 31.4 & 13.2 & 1.9 & 487.6 & 368.9 \\
\hline
\end{tabular}

The experiment was carried out during September, 2008 to September, 2010, the split zone design was adopted, with fertilization as the main treatment and tillage as the secondary treatment. The conservation tillage experiment of spring corn continuous cropping in winter fallow period was carried out under the condition of conventional full straw returning to the field by using the annual ripening system of spring corn. Three different tillage methods (no-tillage, deep-plowing and ploughing) were set up, and the plot area was $22 \times 5 \mathrm{~m}=110 \mathrm{~m}^{2}$, and there were 9 plots after tillage treatment and fertilization. The tested variety is spring maize Yuyu 22. The sowing dates of corn were April 23rd, 2009 and April 19th, 2010, and the harvest dates were September 22nd, 2009 and September 19th, 2010. No irrigation treatment was carried out during the experiment.

According to the investigation results of conventional fertilization in Weibei dry maize field and the balanced fertilization scheme of Shaanxi Provincial Agriculture Department, three kinds of fertilization treatments were set up in this experiment: Balanced fertilization: $\mathrm{N} 150, \mathrm{P}_{2} \mathrm{O}_{5} 120$

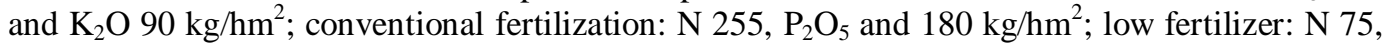


$\mathrm{P}_{2} \mathrm{O} 60$ and $\mathrm{K}_{2} \mathrm{O} 45 \mathrm{~kg} / \mathrm{hm}^{2}$. Among them, nitrogen fertilizer, phosphate and potassium fertilizer are urea, diammonium phosphate and potassium chloride, respectively. During the sowing of spring corn, fertilizer was applied according to fertilization treatment, and the stubble was chopped by rotary tillage, the surface was leveled and mixed fertilizer was used to sow seeds uniformly according to the sowing rate of $60 \mathrm{~kg} / \mathrm{hm}^{2}$.

The following three kinds of soil tillage treatments were carried out immediately after the full straw was returned to the field during the previous corn harvest: a) Ploughing: ploughing 22-25 $\mathrm{cm}$, after the previous corn harvest, all the straw residues were buried in the ploughed soil, and the surface was loose and exposed for the winter fallow period. b) Deep-plowing: when the previous corn was harvested, the surface was covered by $20-30 \mathrm{~cm}$ straw, and leaved straw deep pine 35-40 $\mathrm{cm}$ with 40-60 cm width per interval. c) No tillage: no soil tillage measures were taken after the previous corn harvest, so that the ground was covered by $20-30 \mathrm{~cm}$ straw.

A total of 9 treatments were designed in this experiment: (i) balanced fertilization and notillage treatment (BNT), (ii) balanced fertilization and deep-plowing treatment (BDL), (iii) balanced fertilization and ploughing treatment (BP), (iv) conventional fertilization and no-tillage treatment (CNT), (v) conventional fertilization and deep-plowing treatment (CDL), (vi) conventional fertilization and ploughing treatment (CP); (vii) low fertilizer and no-tillage treatment (LFT), (viii) low fertilizer and deep-plowing treatment (LFD), (ix) low fertilizer and ploughing treatment (LFP).

The soil bulk density of $0-60 \mathrm{~cm}$ (the soil was taken every $20 \mathrm{~cm}$ ) was measured by ring knife method before sowing and after harvest of spring maize in 2009 and 2010. Soil bulk density $(P)$ was calculated as following:

$$
P=\left(m_{2}-m_{1}\right) / \mathrm{v}(1+w)
$$

$m_{2}$-ring knife and wet soil mass; $m_{1}$-ring knife mass; v-ring knife volume; $w$-soil water content.

Determination of maximum field capacity means that after full irrigation or precipitation on the land with deep groundwater and drainage, water is allowed to infiltrate fully and its evaporation is prevented. After a certain period of time, the stable soil water content (soil water potential or soil water suction reaches a certain value) can be maintained by soil profile, which is the upper limit of soil water available to most plants. Calculation of soil maximum field capacity (Ws):

$$
\mathrm{Ws}=\left(m_{3}-m\right) /\left(m-m_{1}\right) \times 100 \%
$$

$m_{3}$-ring knife and wet soil mass after drainage; $m$-ring knife and dried soil mass.

Determination of maximum saturated water content refers to the maximum water content when all soil pores are full of water. The maximum saturated soil water content $(\mathrm{Ww})$ was calculated as follows:

$$
\mathrm{W} \mathrm{w}=\left(m_{4}-m\right) /\left(m-m_{1}\right) \times 100 \%
$$

$m_{4}$-ring knife and wet soil mass after water absorption.

The soil moisture of 0-200 cm (the soil was taken every $20 \mathrm{~cm}$ ) was measured by soil drill drying method during the winter fallow period and main growth period of spring maize in 2009 and 2010. Soil water storage and water use efficiency were calculated.

Soil moisture content $=($ wet soil mass-dried soil mass $) /$ dried soil mass $\times 100 \%$

Calculation of soil water storage (Shang et al. 2010; Guo and Huang 2005). 


$$
W=W i \times D i \times H i \times 10 / 100
$$

W represents soil water storage $(\mathrm{mm})$; W $i$ represents soil mass moisture content of layer $I(\%)$; Di represents soil volume mass of layer $I\left(\mathrm{~g} / \mathrm{cm}^{3}\right) ; \mathrm{H} i$ represents the thickness of soil layer $I(\mathrm{~cm})$, in which the volume mass of more than $2 \mathrm{~m}$ was calculated according to the measured value.

Water use efficiency (WUE) refers to the economic yield per unit $(\mathrm{mm})$ of evapotranspiration per unit area (Jin and Huang 2005).

$$
\begin{aligned}
& \mathrm{WUE}=Y / \mathrm{ET} \\
& \mathrm{ET}=P-\Delta S
\end{aligned}
$$

$Y$ stands for economic yield $\left(\mathrm{kg} / \mathrm{hm}^{2}\right) ; E T$ for evapotranspiration during crop growth (mm); $P$ for precipitation during crop growth $(\mathrm{mm}) ; \Delta \mathrm{S}$ for the difference in soil water storage between harvest and sowing of $0-200 \mathrm{~cm}(\mathrm{~mm})$. The experimental land is dry land without irrigation.

Economic benefits are net income $\left(y u a n / \mathrm{hm}^{2}\right)=$ output income - total input, output income $\left(y\right.$ yan $\left./ \mathrm{hm}^{2}\right)=$ grain yield $\times$ market price, in which the total cost input includes mechanical expenses of sowing and tillage treatment, pesticides, chemical fertilizers, seed costs and labor inputs.

In the experiment, Excel 2003 was used to process the data and charts, and DPS3.01 data processing software were used to analyze the variance of the data and multiple comparisons of the new Duncan complex difference method (Tang and Feng 2007).

\section{Results and Discussion}

In the annual maturity of Weibei area, soil bulk density is affected by soil moisture, climate and other factors. The change of different crop growth periods was the first considering factor to study its change law. It can be seen from Table 2 that the bulk density of soil after harvest was higher than that before sowing, because after a growing period, under the influence of its own gravity and other factors, soil bulk density increases significantly, and tillage measures have little effect on soil bulk density before sowing, but have a significant effect on post-harvest. The results of 2-year experiment showed that the soil bulk density of $0-20 \mathrm{~cm}$ and $20-40 \mathrm{~cm}$ had the trend of no-tillage > deep-plowing > ploughing, and the change of soil bulk density was not significant in the two years (2009 and 2010). The bulk density increased significantly under no-tillage treatment, even reached the highest $\left(1.63 \mathrm{~g} / \mathrm{cm}^{3}\right)$, which was related to the poor air permeability of soil under no-tillage treatment. In the three different soil layers of 0-20, 20-40 and 40-60 cm, the soil bulk density of no-tillage and deep-plowing increased by 9.9, 6.6, 4.1, 2.6 and 5\%, respectively. The field capacity and saturated water content in the surface layer were higher than those in the deep layer, and the results of different tillage treatments in $0-20$ and $40-60 \mathrm{~cm}$ soil layers were as follows: deep-plowing > no-tillage > ploughing. Compared with ploughing, the average field capacity of deep-plowing and no-tillage treatments increased by 15.6, 3.4, 5.1 and $0.2 \%$, respectively, and the saturated water content increased by 18.4, 3.1, 6.7 and $0.6 \%$, respectively. Different tillage treatments of $20-40 \mathrm{~cm}$ soil layer showed deep-plowing > ploughing > no-tillage. The average field capacity of deep-plowing and ploughing was 13.4 and $11.5 \%$ higher than that of no-tillage treatment, and the saturated water content was 14.6 and $12 \%$ higher than that of no-tillage treatment. From this point of view, compared with no-tillage and ploughing, deep-plowing is a better tillage treatment, which is more beneficial to increase field water capacity and saturated water content. 
Table 2. Effects of balanced fertilization and different tillage methods on soil bulk density, field capacity and saturated water content of $40 \mathrm{~cm}$ soil layer in corn field.

\begin{tabular}{|c|c|c|c|c|c|c|c|c|}
\hline \multirow[b]{2}{*}{ Year } & \multirow[b]{2}{*}{$\begin{array}{l}\text { Soil } \\
\text { layer } \\
(\mathrm{cm})\end{array}$} & \multirow[b]{2}{*}{ Treatments } & \multicolumn{3}{|c|}{ Before sowing } & \multicolumn{3}{|c|}{ After harvest } \\
\hline & & & $\begin{array}{c}\text { Bulk } \\
\text { density } \\
\left(\mathrm{g} / \mathrm{cm}^{3}\right)\end{array}$ & $\begin{array}{l}\text { Maximum } \\
\text { field } \\
\text { capacity }(\%)\end{array}$ & $\begin{array}{l}\text { Saturated } \\
\text { water } \\
\text { content }(\%)\end{array}$ & $\begin{array}{c}\text { Bulk } \\
\text { density } \\
\left(\mathrm{g} \cdot \mathrm{cm}^{-3}\right)\end{array}$ & $\begin{array}{l}\text { Maximum } \\
\text { field } \\
\text { capacity }(\%)\end{array}$ & $\begin{array}{l}\text { Saturated } \\
\text { water } \\
\text { content }(\%)\end{array}$ \\
\hline \multirow[t]{9}{*}{2009} & $0-20$ & NT & 1.39 & 28.96 & 30.49 & 1.46 & 27.87 & 31.17 \\
\hline & & DL & 1.37 & 30.54 & 31.8 & 1.36 & 30.68 & 33.94 \\
\hline & & $\mathrm{P}$ & 1.25 & 26.99 & 28.57 & 1.40 & 26.14 & 29.43 \\
\hline & $20-40$ & NT & 1.42 & 29.9 & 31.23 & 1.53 & 26.14 & 28.45 \\
\hline & & DL & 1.31 & 35.57 & 37.43 & 1.51 & 27.74 & 30.81 \\
\hline & & $\mathrm{P}$ & 1.34 & 34.02 & 35.24 & 1.41 & 27.08 & 30.08 \\
\hline & $40-60$ & NT & 1.44 & 27.15 & 28.20 & 1.51 & 29.92 & 31.70 \\
\hline & & DL & 1.46 & 25.98 & 27.22 & 1.49 & 27.95 & 30.94 \\
\hline & & $\mathrm{P}$ & 1.37 & 25.36 & 27.30 & 1.45 & 25.54 & 28.56 \\
\hline \multirow[t]{9}{*}{2010} & $0-20$ & NT & 1.49 & 27.95 & 28.37 & 1.52 & 27.17 & 28.3 \\
\hline & & DL & 1.48 & 35.77 & 36.58 & 1.47 & 30.38 & 31.67 \\
\hline & & $\mathrm{P}$ & 1.28 & 26.82 & 27.42 & 1.40 & 26.66 & 27.7 \\
\hline & $20-40$ & NT & 1.58 & 22.69 & 22.99 & 1.63 & 22.45 & 23.44 \\
\hline & & DL & 1.49 & 28.71 & 29.70 & 1.61 & 22.74 & 23.69 \\
\hline & & $\mathrm{P}$ & 1.46 & 25.65 & 26.22 & 1.57 & 26.07 & 27.34 \\
\hline & $40-60$ & NT & 1.46 & 26.72 & 27.07 & 1.47 & 24.54 & 25.49 \\
\hline & & DL & 1.47 & 28.02 & 28.76 & 1.44 & 31.83 & 33.12 \\
\hline & & $\mathrm{P}$ & 1.42 & 25.93 & 26.38 & 1.36 & 31.35 & 29.55 \\
\hline
\end{tabular}

NT: no-tillage treatment; DL: deep-plowing treatment; P: ploughing treatment.

During the whole growth period, the average soil water storage of no-tillage, deep-plowing and ploughing treatments were $398.4,383.9$ and $352.3 \mathrm{~mm}$, respectively, which were 46.1 and $31.6 \mathrm{~mm}$ higher than that of ploughing treatment (Fig. 1). The water consumption of the three cornfields was $425.3,412.3$ and $406.7 \mathrm{~mm}$, respectively. The order of water consumption was notillage > deep-plowing > ploughing. The results of 2-year experiment showed that the average soil water storage of $0-200 \mathrm{~cm}$ under no-tillage, deep-plowing and ploughing were 400.7, 391.2 and $356.5 \mathrm{~mm}$, respectively. The average soil water storage of no-tillage and deep-plowing treatment was 44.2 and $34.6 \mathrm{~mm}$ higher than that of ploughing treatment at $0-200 \mathrm{~cm}$. As a result, it may be concluded that no-tillage deep-plowing and ploughing have a good effect of storing water and preserving soil moisture.

Before the big trumpet stage, the soil water storage decreased rapidly due to the large amount of water consumed by the vegetative growth of spring maize, and the change trend of soil moisture content of the three different tillage treatments was similar in the big trumpet stage. Results presented in Fig. 2 showed that during the corn trumpet mouth period in 2009, the soil moisture 
content of 0-200 cm under no-tillage, deep-plowing and ploughing treatments varied from 9.3 to $17.2 \%, 10.7$ to $17.4 \%$ and 9.5 to $15.6 \%$, respectively. The average soil moisture content of $0-200$ $\mathrm{cm}$ under the three tillage treatments were $14.9,15.2$ and $13.6 \%$, respectively. Compared with ploughing, no-tillage and deep-plowing were increased by 1.3 and $1.6 \%$, respectively. In the corn trumpet mouth period in 2010, the soil moisture content of $0-200 \mathrm{~cm}$ under no-tillage, deepplowing and ploughing treatments varied from 10.5 to $14.7 \%, 10.1$ to $15.2 \%$ and 11.6 to $15.8 \%$, respectively. The average soil moisture content of $0-200 \mathrm{~cm}$ under the three tillage treatments was $14.5,13.7$ and $12.9 \%$, respectively. Compared with ploughing, no-tillage and deep-plowing were increased by 1.6 and $0.8 \%$, respectively. The results of 2 -year experiments showed that notillage and deep-plowing tillage had better water storage effect than ploughing.
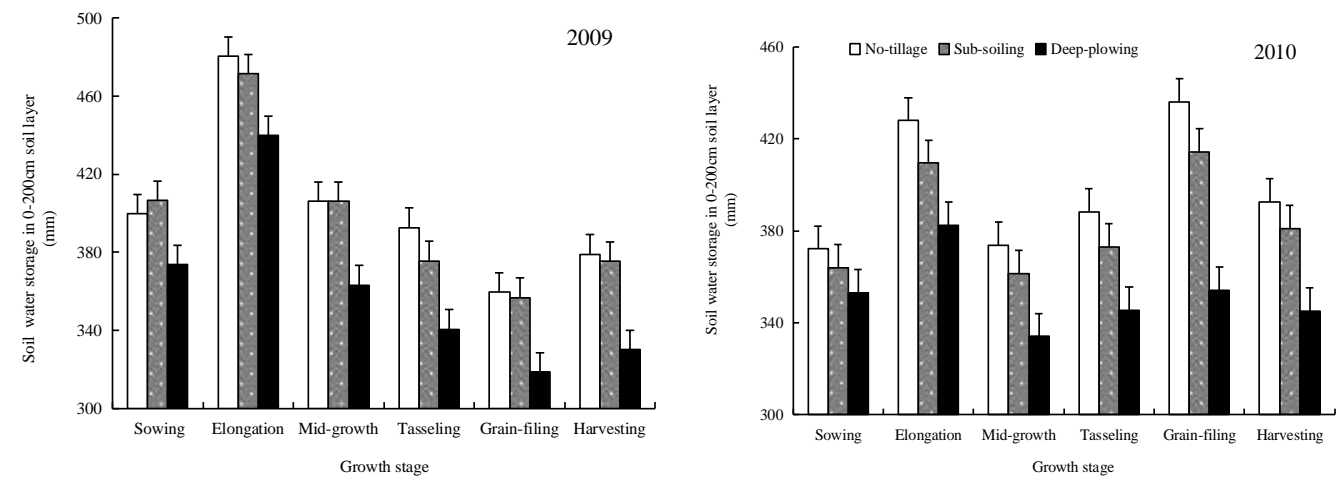

Fig. 1. Dynamic changes of soil water storage in $0-200 \mathrm{~cm}$ soil layer during the growth period of spring maize.
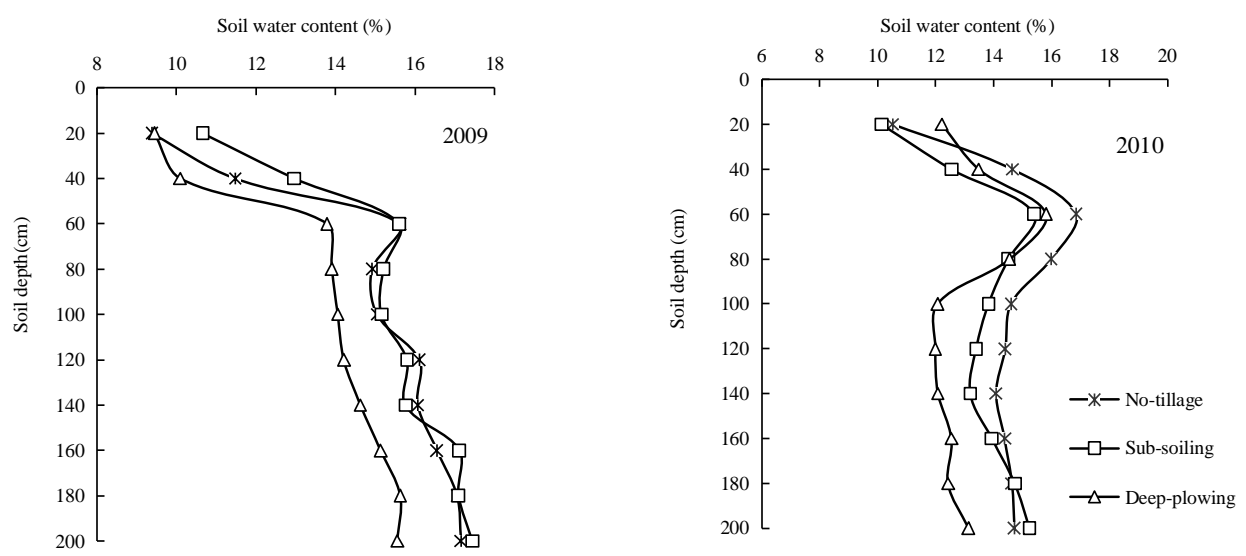

Fig. 2. Comparison of soil moisture in soil layer of $200 \mathrm{~cm}$ under different tillage treatments in big trumpet mouth stage of spring maize.

Effects of different fertilization levels and different tillage measures on the main yield characters of spring maize were different (Table 3). It can be seen that in 2009, under balanced fertilization treatment, maize yield was balanced deep-plowing > balanced no-tillage > balanced ploughing, and balanced deep-plowing was significantly different from balanced no-tillage and balanced ploughing $(\mathrm{p}<0.05)$, but there was no significant difference between balanced no-tillage 
and balanced ploughing. In conventional fertilization, the 1000-grain weight of no-tillage was $20.7 \mathrm{~g}$ higher than that of conventional deep-plowing, while in the low fertilizer treatment, the 1000-grain weight of no-tillage was the highest, which was $35.9 \mathrm{~g}$ higher than that of low-fertilizer deep-plowing. Generally speaking, different fertilization treatments had significant effects on yield and its components. The number of hectare panicles of balanced fertilization and conventional fertilization were 1.9 and $7.5 \%$, respectively higher than that of low fertilizer treatment. In terms of 1000-grain weight, the balanced fertilization treatment was $11.4 \mathrm{~g}$ higher than that of the low fertilizer treatment, and the difference between two treatments was significant. In terms of yield, balanced fertilization > conventional fertilization $>$ low fertilizer treatment, and the difference of maize yield between balanced fertilization and low fertilizer treatment reached a significant level $(\mathrm{p}<0.05)$.

Table 3. Comparison of yield and components of spring maize under different fertilization and tillage treatments.

\begin{tabular}{clcccc}
\hline Year & Treatments & $\begin{array}{c}\text { Number of panicles per } \\
\text { unit area }\left(10^{4} / \mathrm{hm}^{2}\right)\end{array}$ & $\begin{array}{c}\text { Number of grains } \\
\text { per spike (No.) }\end{array}$ & $\begin{array}{c}1000 \text {-grain } \\
\text { weight }(\mathrm{g} / 1000)\end{array}$ & $\begin{array}{c}\text { Output } \\
\left(\mathrm{kg} / \mathrm{hm}^{2}\right)\end{array}$ \\
\hline & BNT & 46542 & 511 & 329.1 & $8236.7 \mathrm{~b}$ \\
& BDL & 47505 & 532 & 312.7 & $8979.6 \mathrm{a}$ \\
& BP & 45809 & 506 & 306.0 & $8021.4 \mathrm{~b}$ \\
& LFT & 47032 & 435 & 303.4 & $5877.8 \mathrm{e}$ \\
& LFD & 45619 & 457 & 267.5 & $6561.1 \mathrm{~d}$ \\
& LFP & 44549 & 525 & 280.2 & $5855.6 \mathrm{e}$ \\
& CNT & 49101 & 524 & 311.7 & $7169.3 \mathrm{c}$ \\
& CDL & 50641 & 498 & 291.0 & $8026.4 \mathrm{~b}$ \\
& CP & 47798 & 565 & 327.0 & $6968.9 \mathrm{~cd}$ \\
& BNT & 48333 & 569 & 345.7 & $9440.4 \mathrm{ab}$ \\
BDL & 49067 & 513 & 346.9 & $9685.1 \mathrm{a}$ \\
BP & 44000 & 492 & 319.2 & $7543.6 \mathrm{~d}$ \\
LFT & 47600 & 538 & 319.8 & $7470.7 \mathrm{~cd}$ \\
LFD & 46367 & 506 & 295.3 & $697.6 \mathrm{e}$ \\
LFP & 47600 & 512 & 313.3 & $7672.9 \mathrm{de}$ \\
CNT & 47833 & 567 & 334.7 & $9096.5 \mathrm{~b}$ \\
CDL & 47933 & 476 & 312.2 & $7571.7 \mathrm{~cd}$ \\
\hline CP & 48700 & & & \\
\end{tabular}

BNT: balanced fertilization and no-tillage treatment; b) BDL: balanced fertilization and deep-plowing treatment; c) BP: balanced fertilization and ploughing treatment; d) LFT: low fertilizer and no-tillage treatment; e) LFD: low fertilizer and deep-plowing treatment ; f) LFP: low fertilizer and ploughing treatment; g) CNT: conventional fertilization and no-tillage treatment; h) CDL: conventional fertilization and deepplowing treatment; i) CP: conventional fertilization and ploughing treatment. In the same column, lowercase letters represent significant differences at the $5 \%$ level of statistical test. The following is the same. 
In 2010, under the treatment of balanced fertilization, the yield of maize of balanced deepplowing was the highest, and followed by deep-plowing balanced no-tillage and balanced ploughing. There was no significant difference between balanced deep-plowing and balanced notillage, while the difference between balanced no-tillage and balanced ploughing was significant ( $\mathrm{p}<0.05)$, there was also significant difference between balanced no-tillage and balanced ploughing $(\mathrm{p}<0.05)$. In the conventional fertilization, the 1000-grain weight of deep-plowing was $21.4 \mathrm{~g}$ which was higher than that of conventional no-tillage, and in the low fertilizer treatment, the 1000-grain weight of low fertilizer deep plowing was the highest, $24.5 \mathrm{~g}$ which was higher than that of low fertilizer ploughing. The effect of fertility on yield was balanced fertilization > conventional fertilization > low fertilizer treatment.

According to the analysis of Tables 3 and 4, the yield and water use efficiency (WUE) of spring maize were significantly different among different fertilization treatments. In different years, the yield and WUE of deep-plowing treatment was the highest, followed by no-tillage, and ploughing treatment was the lowest. In 2009, the average maize yield of no-tillage, deep-plowing and ploughing treatments were $7094.6,7855.7$ and $7855.7 \mathrm{~kg} / \mathrm{hm}^{2}$, respectively. Compared with ploughing, the average maize yield of no-tillage and deep-plowing treatments increased by 2.1 and $13.1 \%$, respectively. The average WUE of no-tillage, deep-plowing and ploughing treatments were $17.45,18.79$ and $16.51 \mathrm{~kg} /\left(\mathrm{hm}^{2} \cdot \mathrm{mm}\right)$, respectively. Compared with ploughing, the WUE of no-tillage and deep-plowing treatments increased by 5.7 and $13.8 \%$, respectively. In 2010, the average maize yield of no-tillage, deep-plowing and ploughing treatments under the three fertilization treatments were $8094.7,8686.4$ and $7681.7 \mathrm{~kg} /\left(\mathrm{hm}{ }^{2} \cdot \mathrm{mm}\right)$, respectively. Compared with ploughing, the yields of no-tillage and deep-plowing treatments increased by 5.4 and $13.1 \%$, respectively. The average WUE of water use efficiency of no-tillage, deep-plowing and ploughing treatments were $19.96,22.10$ and $19.25 \mathrm{~kg} /\left(\mathrm{hm}^{2} \cdot \mathrm{mm}\right)$, respectively. The WUE of no-tillage and deep-plowing treatments was increased by 3.7 and $14.8 \%$ compared with the ploughing treatment.

Table 4. Changes of water use efficiency (WUE) of spring maize under different fertilization and tillage treatments.

\begin{tabular}{lccc}
\hline Treatment & WUE09 & WUE10 & Average \\
\hline BNT & 19.77 & 21.49 & $20.63 \mathrm{ab}$ \\
BDL & 20.53 & 23.49 & $22.01 \mathrm{a}$ \\
BP & 18.38 & 21.01 & $19.70 \mathrm{ab}$ \\
LFT & 14.29 & 18.43 & $16.36 \mathrm{~d}$ \\
LFD & 16.09 & 20.38 & $18.24 \mathrm{bc}$ \\
LFP & 14.4 & 17.1 & $15.75 \mathrm{e}$ \\
CNT & 18.29 & 19.96 & $19.13 \mathrm{bc}$ \\
CDL & 19.75 & 22.43 & $21.09 \mathrm{ab}$ \\
CP & 16.76 & 19.63 & $18.20 \mathrm{bc}$ \\
\hline
\end{tabular}

Under different tillage treatments, there were significant differences both in maize yield and WUE among different fertilization treatments, with the highest in balanced fertilization, the second in conventional fertilization and the lowest in low fertilizer treatment in the above two indexes (maize yield and WUE). In 2009, the average yield of maize under balanced fertilization, conventional fertilization and low fertilizer treatment were 8412.6, 7388.2, $6098.2 \mathrm{~kg} / \mathrm{hm}^{2}$, 
respectively, and the yield of balanced fertilization and conventional fertilization were 38.0 and $17.5 \%$ higher than that of low fertilizer treatment, respectively. The average WUE of balanced fertilization, conventional fertilization and non-fertilizer treatments were 19.56, 18.27 and 14.93 $\mathrm{kg} /\left(\mathrm{hm}^{2} \cdot \mathrm{mm}\right)$, respectively, balanced fertilization and conventional fertilization increased 31.0 and $22.4 \%$ compared with low fertilizer treatment WUE. In 2010, the average yield of maize under balanced fertilization, conventional fertilization and low fertilizer treatment were 9 123.1, 7880.4 and $7459.3 \mathrm{~kg} / \mathrm{hm}^{2}$, respectively. Compared with low fertilizer treatment, the yield of maize with balanced fertilization and conventional fertilization were increased by 22.3 and $5.6 \%$. The average WUE of balanced fertilization, conventional fertilization and non-fertilizer treatment were 22.00 , 20.67, $18.63 \mathrm{~kg} /\left(\mathrm{hm}^{2} \cdot \mathrm{mm}\right)$, respectively, balanced fertilization and conventional fertilization treatment increased 18.1 and $10.9 \%$ compared with non-fertilizer treatment WUE. The results of 2-year experiments showed that among the 9 combinations of fertilization and tillage, the yield and WUE treated with balanced fertilization and deep-plowing were the highest, and the average yield and WUE in 2-year were $9332.4 \mathrm{~kg} / \mathrm{hm}^{2}$ and $22.01 \mathrm{~kg} /\left(\mathrm{hm}^{2} \cdot \mathrm{mm}\right)$, the following was the combination of balanced fertilization and no-tillage, and the average yield and WUE in 2-year were 8688.6 and $20.63 \mathrm{~kg} /\left(\mathrm{hm}^{2} \cdot \mathrm{mm}\right)$, respectively. Therefore, balanced fertilization and deepplowing treatment are the best combination to increase yield and improve water use efficiency.

Under the fertilization treatments from 2009 to 2010, the average input costs of no-tillage, deep-plowing and ploughing treatments were $6937.2,7612.2$ and 7462.2 yuan/hm ${ }^{2}$, respectively (Table 5). The average net income of each tillage treatment were $4090.1,4393.3$ and 3155.8 yuan $/ \mathrm{hm}^{2}$, respectively. Compared with ploughing, the income of no-tillage and deep-plowing treatments increased by 934.3 and 1237.6 yuan $/ \mathrm{hm}^{2}$, and the increase rate were 29.6 and $39.2 \%$, respectively. Under each tillage treatment, the average input cost of balanced fertilization, conventional fertilization and low fertilizer treatment were 8163.4, 6932.1 and $6916.1 \mathrm{yuan} / \mathrm{hm}^{2}$, respectively. The average net income of each fertilization treatment was 4560.6, 4145.1 and $2933.5 y u a n / \mathrm{hm}^{2}$, respectively. The average net income of balanced fertilization and conventional fertilization were 1627.1 and $1211.5 \mathrm{yuan} / \mathrm{hm}^{2}$ higher than that of low fertilizer treatment, and the increase rates were 55.4 and $41.3 \%$, respectively.

Table 5. Corn production cost and economic benefit unit of different fertilization and tillage treatments $\left(\right.$ yuan $\left./ \mathbf{h m}^{2}\right)$.

\begin{tabular}{llllllll}
\hline Year & Treatment & $\begin{array}{l}\text { Fertilizer } \\
\text { input }\end{array}$ & $\begin{array}{l}\text { Mechanical } \\
\text { operation input }\end{array}$ & $\begin{array}{l}\text { Other } \\
\text { input }\end{array}$ & $\begin{array}{l}\text { Total } \\
\text { input }\end{array}$ & $\begin{array}{l}\text { Output } \\
\text { income }\end{array}$ & Net income \\
\hline 2009 & BNT & 2494.7 & 1200.0 & 4068.8 & 7763.4 & $11696.1 \mathrm{~b}$ & $3932.7 \mathrm{abc}$ \\
& BDL & & 1875.0 & & 8438.4 & $12751.1 \mathrm{a}$ & $4312.7 \mathrm{a}$ \\
& BP & & 1725.0 & & 8288.4 & $11390.4 \mathrm{~b}$ & $3101.9 \mathrm{bc}$ \\
& LFT & 1247.3 & 1200.0 & & 6516.1 & $8346.4 \mathrm{~d}$ & $1830.4 \mathrm{bc}$ \\
& LFD & & 1875.0 & & 7191.1 & $9316.8 \mathrm{~cd}$ & $2125.7 \mathrm{abc}$ \\
& LFP & 1725.0 & & 7041.1 & $8314.9 \mathrm{~d}$ & $1273.8 \mathrm{c}$ \\
& CNT & 1263.4 & 1200.0 & & 6532.1 & $10180.5 \mathrm{bc}$ & $3648.3 \mathrm{ab}$ \\
& CDL & & 1875.0 & & 7207.1 & $11397.5 \mathrm{~b}$ & $4190.4 \mathrm{a}$ \\
& CP & 1725.0 & & 7057.1 & $9895.9 \mathrm{c}$ & $2838.8 \mathrm{bc}$ \\
& BNT & 2494.7 & 1200.0 & & 7763.4 & $13527.8 \mathrm{ab}$ & $5764.4 \mathrm{ab}$ \\
& BDL & 1875.0 & 8438.4 & $14333.9 \mathrm{a}$ & $5895.5 \mathrm{a}$ \\
\hline
\end{tabular}




\begin{tabular}{llllll}
\hline BP & & 1725.0 & 8288.4 & $12644.5 \mathrm{bc}$ & $4356.1 \mathrm{abc}$ \\
LFT & 1247.3 & 1200.0 & 6516.1 & $11056.6 \mathrm{~cd}$ & $4540.5 \mathrm{bc}$ \\
LFD & & 1875.0 & 7191.1 & $11806.8 \mathrm{c}$ & $4615.7 \mathrm{ab}$ \\
LFP & 1725.0 & 7041.1 & $10255.9 \mathrm{~d}$ & $3214.9 \mathrm{~d}$ \\
CNT & 1263.4 & 1200.0 & 6532.1 & $11355.8 \mathrm{~cd}$ & $4823.8 \mathrm{bc}$ \\
CDL & & 1875.0 & 7207.1 & $12426.8 \mathrm{bc}$ & $5219.7 \mathrm{abc}$ \\
CP & 1725.0 & 7057.1 & $11206.16 \mathrm{~d}$ & $4149.0 \mathrm{~cd}$ \\
\hline
\end{tabular}

The mechanical operation input includes sowing, straw returning and subsoiling or ploughing farmland input, and other inputs include pesticide, seed and manual input. Among them, fertilizer diammonium was 3.1 yuan $/ \mathrm{kg}$, urea was 2.2 yuan $/ \mathrm{kg}$, potash fertilizer was 5.2 yuan $/ \mathrm{kg}$, deep-plowing was $675 \mathrm{yuan} / \mathrm{hm}^{2}$, ploughing was 525 yuan $/ \mathrm{hm}^{2}$, and the corn prices in 2009 and 2010 were 1.42 and 1.48 yuan $/ \mathrm{kg}$, respectively. In the same column, lowercase letters represent a significant difference in $5 \%$ of the statistical test.

The results of two-year experiments showed that among the 9 combinations of fertilization and tillage, the net income of the treatment of deep plowing with balanced fertilization was the highest, with an average of $5104.1 \mathrm{yuan} / \mathrm{hm}^{2}$, followed by the treatment of balanced fertilization and no-tillage, and the average net income was 4914.3 yuan $/ \mathrm{hm}^{2}$, the last was that of conventional fertilization and deep-plowing treatment, and the average net income was $4705.1 \mathrm{yuan} / \mathrm{hm}^{2}$.

Tillage measures had no significant effect on soil bulk density before sowing, but had significant effect on soil bulk density after harvest. The soil bulk density of no-tillage was higher than that of traditional tillage and the soil bulk density was significantly increased. Ploughing could keep the soil bulk density maintain at a low level. The effect of water storage and soil moisture conservation of no-tillage and deep-plowing tillage treatments was better than that of ploughing treatments. The deep -plowing treatment showed better water storage capacity and high water use efficiency, and the combination of balanced fertilization and deep -plowing tillage was beneficial to increase income and yield of spring maize in Weibei Arid Highland, which is a suitable planting mode of spring maize conservation tillage in Weibei dry plateau.

\section{Acknowledgements}

This study was financially supported by the Shaanxi Province Innovative Talents Promotion Plan Young Science and Technology Rising Star Project (2021KJXX-88), Shaanxi Provincial Natural Science Basic Research Program Project (2021JZ-57), Funded by Technology Innovation Center for Land Engineering and Human Settlements, Shaanxi Land Engineering Construction Group Co.,Ltd and Xi'an Jiaotong University (2021WHZ0087, 2021WHZ0093).

\section{References}

Fang RR, Tong YA, Zhao EL and Liang DL 2003. Effect of conservation tillage on moisture, fertility and yield in Weibei Highland. Agr. R. Arid Areas 21(1): 55-57.

Hatfield JL, Sauer TJ and Prueger JH 2001. Managing soils to achieve greater water use efficiency. Agron. J. 93(2): 271-280.

Huang GB, Guo QY, Zhang R, Feng L, Chan KY and Yu AZ 2006. Effects of conservation tillage on soil moisture and crop yield in a phased rotation system with spring wheat and field pea in dryland. Acta Ecolo. Giga. Sinica 26(4): 1176-1185.

Ji ZS, Wang SX, Luo XT, Yan XM, Fan LY, Zhang ZQ, Luo XT, Wu JF and Zhang XJ 1998. A study on soil Nutrient with no tillage in dryland corn field. Acta Agr. Boreali Sin. 3: 63-68. 
Li YJ, Huang M, Wu JZ, Yao YQ and Lv JJ 2006. Effects of different tillage on utilization and run-off of water and nutrient in sloping farmland of Yuxi dryland area. J. Soil Water Conser. 20(2): 42-45.

Liu LJ, Gao HW and Li HW 2004. Conservation tillage for corn-wheat two crops a year region. Trans. CSAE 20(3): 70-73.

Song XY, Liu XZ, Shen WJ and Shi WJ 2004. Problems of resources and the measures for the regulation of planting structure in the Weibei rainfed highland in Shaanxi province. Arid Land Geogr. 27(2): 199-201.

Shang JX, Li J, Jia ZK, Zhang LH 2010. Soil water conservation effect, yield and income increments of conservation tillage measures in spring maize field on Weibei highland. Sci. Agr. Sinica 43(13): 26682678.

Shi JL, Liu JZ and Wu FQ 2006. Research advances and comments on conservation tillage. Agr. R. Arid Areas 24(1): 205-210.

Tang QY and Feng MG 2007. DPS ${ }^{\odot}$ Data Processing System. Beijing: Science Press 115-128.

Wang SX, Wang ZJ, Zuo Z, Guo YZ 2004. Effects of difference mulching on the soil environment and maize yield in rain fed land. J. Arid Land Resour. Environ. 18: 134-137.

Zhang HL, Gao WS, Chen F and Zhu WS 2005. Prospects and present situation of conservation tillage. J. China Agr. U. 10(1): 16-20.

Zheng HP 2004. Study on the comprehensive effect of conservation tillage measures and its ecological and economic benefit evaluation. Gansu Agr. U.

Zhou H, Lv YZ, Yang ZC, Li BG 2007. Effects of conservation tillage on soil aggregates in Huabei Plain, China. Sci. Agr. Sinica 40(9): 1973-1979.

(Manuscript received on 19 May, 2021; revised on 20 July, 2021) 